\title{
MITOLOGI SAEDAH SAENIHz CERITA RAKYAT DARI INDRAMAYU
}

\section{THE MYTHOLOGY OFSAEDAH SAENIH: FOLKLORE OF INDRAMAYU}

\author{
Yuzar Purnama \\ Balai Pelestarian Nilai Budaya (BPNB) Jawa Barat \\ Jl. Cinambo No. 136 Ujungberung-Bandung 42094 \\ e-mail: yuzarpurnama@gmail.com
}

\begin{abstract}
Abstrak
Masyarakat Indramayu sebagian masih kental dengan adat istiadat nenek moyangnya. Di beberapa wilayah merupakan tumbuh kembangnya kesenian tradisional, kepercayaan, upacara tradisional, permainan tradisional, dan cerita rakyat. Pada kesempatan ini, penulis ingin mengkaji mitologi dalam cerita rakyat Saedah Saenih. Keberadaan cerita Saedah Saenih sangat melekat bagi sebagian masyarakat Indramayu, seolah cerita ini nyata. Begitu terkenalnya sehingga acapkali cerita ini muncul dalam drama, syair lagu, bahkan pernah dibuat filmnya. Permasalahan dituangkan dalam bentuk pertanyaan, mitos apa yang terdapat dalam cerita Saedah Saenih? Sejauh mana mitos Saedah Saenih bagi masyarakatnya? Nilai luhur apa yang terkandung dalam cerita Saedah Saenih? Penelitian ini bertujuan untuk mendapatkan gambaran yang lengkap dan jelas tentang mitologi dalam cerita rakyat Saedah Saenih. Penelitian ini menggunakan pendekatan kualitatif dengan metode penelitian deskriptif. Penelitian diawali studi pustaka, pengumpulan data, klasifikasi, analisis dan pelaporan. Simpulan, mitos cerita Saedah Saenih sangat melekat pada masyarakat Indramayu. Isi cerita dianggap nyata ditandai dengan kepercayaan bahwa keberadaan Saenih masih ada di Sungai Sewo dalam jelmaan buaya putih. Kepatuhan berupa lemparan uang, saat melewati jembatan Sewo untuk menghindarkan diri dari petaka .Mereka pun percaya Sarkawi menjelma menjadi bale kambang, Maemunah menjadi pring ori, dan Saedah menjadi pohon di tepi Sungai Sewo.
\end{abstract}

Kata kunci: mitologi, cerita rakyat Saedah Saenih,Kabupaten Indramayu.

\begin{abstract}
Indramayu community still believe with the customs of his ancestors. In some areas, we can found the traditional arts, beliefs, ceremonies, games and story. On this occasion, the writers wanted to examine folklore mythology Saedah Saenih. The existences of Saenih Saedah story is very attached to some people in Indramayu, as if the story is real. The story is famous, and it appeared in the drama, lyrics, and even once made into a movie. The problems outlined in the form of questions, the myth of what is contained in the story Saedah Saenih? How far the myth Saedah Saenih for the community? what moral values that is contain in the story Saedah Saenih? This study aims are to get a complete and clear picture of the mythology in Saedah Saenih folklore. This study used a qualitative approach with descriptive method. The study begins literature, data collection, classification, analysis and reporting. In conclusion, the mythical story Saenih Saedah very attached to the people of Indramayu. The contents are considered real story is characterized by the belief that the existence Saenih still in the river Sewo in white crocodile manifestation. Compliance form of throw money, as it passes through the bridge Sewo to avoid disaster. They also believe Sarkawi transformed into a floating bale, Maemunah be pring ori, and Saedah into a tree on the river bank Sewo.
\end{abstract}

Keywords: mythology, traditional story of Saedah Saenih, Indramayu Regency. 


\section{A. PENDAHULUAN}

Keberadaan tradisi lisan lebih dahulu daripada tradisi tulisan. Era tradisi lisan disinyalir lebih tua daripada era tradisi tulisan. Komunikasi secara lisan mengawali era peradaban sebelum ditemukan teknologi menulis. Namun, di antara kedua peradaban yakni era tradisi lisan dan tradisi tulisan, keduanya memiliki kelebihan dan kekurangan masing-masing. Keduanya merupakan masa jaya bagi para pendukungnya.Walter J. Ong mengatakan bahwa kelisanan sesungguhnya mengalami tahapan-tahapan tertentu sesuai dengan zamannya. Bahasa pada hakikatnya bersifat lisani (oral). Begitu lisannya sehingga seakan-akan aksara tidak diperlukan. Dalam bukunya Orality and Literacy: The Technologizing of the World, Ong memperlihatkan tahapan-tahapan perkembangan kebudayaan kelisanan mulai kelisanan tahap awal, era tulisan, masa mesin cetak mengubah peradaban, dan masa ketika elektronik mulai berperan, ketika manusia memasuki masa kelisanan (Yeni, 2012: 409-410).

Indonesia mulai mengenal tulisan atau tradisi tulisan pada abad ke-5. Diena Putra dan Ekadjati mengatakan bahwa seiring perkembangan zaman, ketika manusia mengenal budaya tulis yang di Indonesia dikenal pada abad ke-5 (Sabana ed, 2005: 20, 55).

Tradisi lisan adalah bentuk komunikasi antarmasyarakat dengan tidak menggunakan media alat tulis atau tulisan. Tradisi lisan mengandalkan daya ingat, oleh karena itu pada masa ini daya ingat seseorang merupakan faktor utama dalam menyerap dan mentransfer informasi dan ilmu pengetahuan. Menurut Yeni (2012:407) tradisi lisan adalah warisan leluhur yang banyak menyimpan kearifan lokal, kebijakan, dan filosofi hidup yang terekspresikan dalam bentuk mantera, petatah-petitih, pertunjukan, dan upacara adat. Tradisi lisan yang terdapat di Nusantara, sekaligus juga menyimpam identitas bangsa karena pada tradisi lisan terletak akar budaya dan akar tradisi sebagai subkultur Indonesia.

Produk budaya tradisi lisan di antaranya adalah cerita rakyat, mitos, legenda, dan sebagainya. Ciri tradisi lisan biasanya berkembang atau menyebar dari mulut ke mulut. Produk budayanya bersifat anonim yakni tidak diketahui siapa pengarangnya. Ciri lainnya pada umumnya masyarakat pendukung menganggap bahwa cerita tersebut benar-benar terjadi, sehingga dijadikan tontonan dan tuntunan bagi generasi ke generasi. Menjadi tontonan karena pada masanya cerita rakyat menjadi media hiburan bagi masyarakat pendukung sekaligus menjadi tuntunan karena mereka menganggap bahwa cerita tersebut merupakan amanah atau pesan dari leluhur yang harus menjadi tuntunan bagi mereka.

Salah satu tradisi lisan yang akan diangkat sebagai bahan kajian adalah cerita rakyat Saedah Saenih dari Kabupaten Indramayu. Cerita ini merupakan cerita tragedi anak manusia akibat kemiskinan dan kurangnya kasih sayang orang tua.

Cerita rakyat atau tradisi lisan disebut folklor. James Danandjaya pada tahun 1972 mulai melakukan kajian mendalam tentang tradisi lisan yang diistilahkan dengan folklor Indonesia. Danandjaya mendefinisikan folklor sebagai berikut ....sebagian dari kebudayaan yang tersebar dan diwariskan turun temurun secara tradisional, di antara anggota-anggota kolektif apa saja di Indonesia, dalam versi yang berbeda-beda, baik dalam bentuk lisan maupun dalam bentuk contoh yang disertai dengan perbuatan-perbuatan dan alat-alat bantu pengingat, mnemonic devices (Danandjaya, 1991:460).

Selanjutnya, Danandjaya menjelaskan bahwa folk adalah sekelompok orang yang memiliki ciri-ciri pengenal fisik, sosial dan kebudayaan sehingga dapat dibedakan dari kelompok-kelompok lain, sedangkan yang dimaksud dengan lore adalah tradisi folk, sebagian kebudayaannya yang diwariskan secara 
turun temurun secara lisan atau melalui suatu contoh yang disertai gerak isyarat atau alat bantu pengingat (Danandjaya (ed. Pudentia), 2008:61).

Hampir seluruh masyarakat Indramayu mengenal dan mengetahui isi cerita Saedah Saenih bahkan cerita ini pun terdapat di sebagian masyarakat Cirebon dan masyarakat Sumedang. Kelekatan cerita Saedah Saenih pada masyarakat Indramayu dapat dilihat dalam dramadrama, baik drama cerita dalam kesenian daerah ataupun drama-drama para pelajar sekolah. Dalam beberapa lagu tradisional di Indramayu di antaranya dalam syair lagu kesenian tarling (gitar dan suling), ada sebuah lagu yang menggambarkan penderitaan Saedah Saenih, cerita ini pun pernah dibuatkan filmnya.

Masyarakat Indramayu menganggap bahwa cerita Saedah Saenih ini benarbenar terjadi. Dua kuburan di dekat jembatan Sewo dianggap sebagai kuburan ayah dan ibu tirinya, sedangkan Sadah dianggap mati dan berubah menjadi pohon di tepi Sungai Sewo. Adapun Saenih dianggap berubah menjadi seekor buaya putih penghuni Sungai Sewo.

Kini masyarakat yang melewati jembatan Sungai Sewo akan melemparkan uang recehan, mereka menganggap bahwa apabila tidak memberikan uang atau permisi (pamit) pada penghuni Sungai Sewo akan mendapatkan kecelakaan.

Itulah alasan penulis untuk melakukan kajian mitologi pada cerita rakyat Saedah Saenih. Upaya ini selain sebagai pendokumentasian salah satu khasanah budaya bangsa, juga ingin menggali nilainilai luhur yang terkandung di dalamnya agar bisa diaplikasikan dalam kehidupan sehari-hari.

Tujuan penelitian ini adalah ingin mendapatkan gambaran yang lengkap dan jelas tentang mitologi dalam cerita Saedah Saenih yang begitu digandrungi masyarakat Indramayu. Adapun ruang lingkup bahasan meliputi unsur-unsur mitos dalam cerita Saedah Saenih dan nilai-nilai luhur atau pesan yang terdapat dalan cerita mitos tersebut.

\section{B. METODE PENELITIAN}

Penelitian ini menggunakan metode deskriptif dengan pendekatan kualitatif. Metode yang digunakan dalam penelitian ini adalah metode deskriptif dengan penelaahan data yang memecahkan masalah yang tidak terbatas pada pengumpulan dan penyusunan sampai pada kesimpulan yang didasarkan atas penelitian (Surakhmad, 1982:19).

Pendekatan yang digunakan dalam penelitian ini adalah pendekatan kualitatif. Menurut Bogdan pendekatan kualitatif adalah sebagai prosedur penelitian yang menghasilkan data deskriptif berupa katakata tertulis atau lisan dari orang-orang dan perilaku yang dapat diamati (1972:5). Ratna mengatakan bahwa penelitian kualitatif lebih merujuk pada persoalan "makna" yang membawa pada orientasi teoretisnya. Dalam ranah kajian budaya, sebuah karya sastra dapat dianalisis secara langsung sebab karya itulah yang dianggap sebagai masyarakat (2010: 197). Sementara itu, Taylor mengatakan bahwa penggunaan pendekatan kualitatif dipandang sebagai prosedur penelitian yang dapat diharapkan akan menghasilkan data deskriptif, berupa kata-kata tertulis atau lisan dari sejumlah orang dan perilaku yang dapat diamati (Kahmad, 2000:97). Data yang dikumpulkan berupa kata-kata, gambar, dan bukan angka-angka. Hal ini diterapkan oleh adanya penerapan metode kualitatif (Moleong, 1989:7).

Langkah-langkah penelitian ini diawali dengan studi pustaka, dilanjutkan dengan pengumpulan data, pengklasifikasian data, analisis dan pembuatan artikel. Menurut Patton (dalam Moeleong, 2001:208) analisis data merupakan proses mengatur urutan data, mengorganisasikan ke dalam suatu pola, kategori dan urutan suatu dasar. 


\section{HASIL DAN BAHASAN \\ 1. Selayang Pandang Kabupaten Indramayu}

Kabupaten Indramayu terletak di wilayah administrasi Provinsi Jawa Barat. Lokasinya terdapat di bagian utara Jawa Barat atau dikenal dengan istilah wilayah pantai utara (pantura). Wilayah ini berbatasan dengan Cirebon, Subang dan Jawa Tengah yang berbatasan langsung dengan laut dengan panjang garis pantai 114,1 Km (https://id.wikipedia.org/wiki/ Kabupaten_Indramayu diakses 19 juli 2016 15.47).

Kabupaten Indramayu secara geografis terletak pada $107^{\circ} 52^{\circ}-108^{\circ} 36^{\circ}$ Bujur Timur dan $6^{\circ} 15^{\circ}-6^{\circ} 40^{\circ}$ Lintang Selatan. Sedangkan berdasarkan topografinya sebagian besar merupakan dataran atau daerah landai dengan kemiringan tanahnya rata-rata $0-2 \%$. Keadaan ini berpengaruh terhadap drainase, bila curah hujan cukup tinggi, maka di daerah-daerah tertentu akan terjadi genangan air.

Letak Kabupaten Indramayu yang membentang sepanjang pesisir pantai utara pulau Jawa membuat suhu udara di kabupaten ini cukup tinggi yaitu $28^{\circ}$ Celcius. Sementara rata-rata curah hujan sepanjang tahun 2006 adalah sebesar 61,06 mm. Adapun curah hujan tertinggi terjadi di Kecamatan Kertasemaya kurang lebih sebesar $70 \mathrm{~mm}$ dengan jumlah hari hujan tercatat 2491 hari, sedang curah hujan terendah terjadi di Kecamatan Pasekan kurang lebih sebesar $55 \mathrm{~mm}$ dengan jumlah hari hujan tercatat 683 hari.

Luas wilayah Indramayu mencapai 204.011 ha. Bila dibandingkan dengan luas areal tanah sawah di tahun 2005 yakni 110.548 ha tanah sawah atau $54,19 \%$ dari luas wilayah maka dapat terlihat kecenderungan perubahan penggunaan lahan.

Kabupaten Indramayu terdiri atas 33 kecamatan, yang dibagi lagi atas sejumlah 315 desa dan kelurahan. Pusat pemerintahan berada di Kecamatan Indramayu. Beberapa kecamatan-kecamatan penting di wilayah Kabupaten
Indramayu di antaranya adalah Indramayu, Jatibarang, Haurgeulis, Patrol, Karangampel, dan Terisi.

Walaupun Indramayu berada di Jawa Barat yang notabene adalah tanah Pasundan yang berbudaya dan berbahasa Sunda, namun sebagian besar penduduk Indramayu menggunakan bahasa Cirebon dialek Indramayu, masyarakat setempat menyebutnya dengan Basa Dermayon, yakni dialek bahasa Cirebon yang hampir serupa dengan bahasa Cirebon yang dipergunakan di wilayah pusat Keraton Cirebon di Kota Cirebon. Dalam bahasa Cirebon dialek Indramayu tata bahasanya terbagi menjadi dua yakni Basa Besiken (dipergunakan untuk berbicara dalam tatanan resmi dan menghormati lawan bicara) dan Basa Ngoko (dipergunakan sehari-hari dalam pergaulan). Di bagian selatan dan barat daya kabupaten ini, beberapa wilayah menggunakan bahasa Sunda, mengingat sejarah kabupaten Indramayu yang dulu pernah masuk kedalam wilayah Kerajaan Galuh dan Sumedang Larang di wilayah Selatan, sehingga memengaruhi masyarakatnya berbahasa Sunda Khas Indramayu yang disebut Sunda Parean.

Berikut ini kecamatan-kecamatan yang mempunyai dialek yang berbeda berdasarkan keterangan penelitian dan Peta Budaya Provinsi Jawa barat tahun 2011. Bahasa Cirebon dialek Dermayu: Indramayu, Balongan, Juntinyuat, Kedokanbunder, Karangampel, Krangkeng, Sindang, Jatibarang, Sliyeg, Kertasemaya, Sukagumiwang, Losarang, Lelea (sebagian desa), Cantigi, Lohbener, Widasari, Tukdana, Bangodua, Cikedung, Patrol, Bongas, Gabuswetan, Kandanghaur. Bahasa Sunda: Kandanghaur (sebagian desa), Lelea, dan Haurgeulis. Wilayah dua bahasa atau wilayah percampuran bahasa Sunda dan bahasa Cirebon: Terisi, Kroya, Gantar, Anjatan, dan Sukra.

Hasil bumi Indramayu adalah padi, walaupun bukan penghasil padi terbesar, namun masyarakat Indramayu umumnya 
memiliki mata pencarian sebagai petani, dan sebagian besar wilayah Indramayu merupakan lahan pertanian, bahkan bisa ditemukan persawahan walaupun berada di pusat kota Indramayu.

Hasil bumi lainnya adalah mangga, jenis mangga khas Indramayu sendiri disebut mangga cengkir oleh masyarakat setempat. Mangga ini terkenal enak dan manis, tak ayal di sepanjang jalur utama Indramayu banyak pedagang buah mangga sebagai oleh-oleh khas Indramayu. Dari hasil bumi yang satu inilah, Indramayu mendapat julukan sebagai Kota Mangga.

\section{Sejarah Indramayu}

Putra Tumenggung Gagak Singalodra dari Bengelen Jawa Tengah bernama Raden Wiralodra yang mempunyai garis keturunan Majapahit dan Pajajaran, dalam tapa bratanya di kaki Gunung Sumbing mendapat wangsit "Hai Wiralodra apabila engkau ingin berbahagia berketurunan di kemudian hari, pergilah ke arah matahari terbenam dan carilah lembah Sungai Cimanuk. Manakala telah di sana, berhentilah dan tebanglah belukar secukupnya untuk mendirikan pedukuhan dan menetaplah di sana. Kelak tempat itu akan menjadi subur dan makmur serta tujuh turunanmu akan memerintah di sana.

R. Wiralodra ditemani Ki Tinggil dan berbekal senjata Cakra Undaksana. Tokoh-tokoh lain dengan pendiri pedukuhan dimaksud adalah Nyi Endang Darma yang cantik dan sakti, Aria Kemuning putra Ki Gede Lurah Agung yang diangkat putra oleh Putri Ong Tien, istri Sunan Gunung Jati. Ki Buyut Sidum/Kidang Pananjung seorang pahlawan Panakawan Sri Baduga dari Pajajaran; Pangeran Guru, seorang pangeran dari Palembang yang mengajarkan Kanuragan dengan 24 muridnya. Pedukuhan tersebut berkembang dan diberi nama "Darma Ayu" oleh R. Wiralodra yang diambil dari nama seorang wanita yang dikagumi karena kecantikan dan kesaktiannya "Nyi Endang Darma", serta dapat diartikan "Kewajiban Yang Utama" atau "Tugas Suci". Pedukuhan Cimanuk yang diberi nama "Darma Ayu" yang kemudian berubah menjadi "Indramayu", setelah terbebas dari kekuasaan Pajajaran pada tahun 1527, diproklamirkan berdirinya oleh $\mathrm{R}$. Wiralodra pada hari Jumat Kliwon tanggal 1 Muharam 934H atau 1 Sura 1449 dan jatuh pada tanggal 7 Oktober 1527. Titimangsa tersebut resmi sebagai Hari Jadi Indramayu ${ }^{1}$.

\section{Cerita Rakyat Saedah Saenih a. Sumber Cerita}

Cerita rakyat Saedah Saenih bagi masyarakat Indramayu sudah tidak asing. Cerita ini banyak ditulis baik perorangan maupun kelompok dan instansi. Bahkan cerita ini sudah banyak ditulis dalam skenario baik di sekolah untuk dijadikan drama maupun oleh produser film. Selain itu, cerita Saedah Saenih sering dirilis dalam syair lagu seperti pada kesenian tarling khas Indramayu ini.

Judul yang diberikan dalam cerita rakyat ini pun baik dalam buku-buku, media elektronik (internet), dan judul yang terlontar dari para seniman/budayawan cukup beragam seperti cerita Saeda Saeni, cerita Saedah Saeni, cerita Saeni Saeda, cerita Saeni Saedah, dan cerita Saedah Saenih. Untuk keseragaman, penulis akan mengambil judul dari sebuah buku Sejarah Indramayu yaitu cerita rakyat Saedah Saenih.

Salah satu sumber cerita Saedah Saenih yang akan dijadikan bahan kajian diambil dari Sejarah Indramayu (HA. Dasuki, 1964: 335-337). Sebagai pembanding, penulis mengambil versi lain yang diambil dari media internet. Alasannya karena banyak cerita Saedah Saenih yang ditulis dalam internet dengan versi-versi yang berbeda.

\footnotetext{
${ }_{1}$ https://id.wikipedia.org/wiki/Kabu-paten_Indramayu diakses 19 juli 2016 15.47.
} 


\section{b. Ringkasan Cerita Saedah Saenih}

Di suatu kampung tersebutlah sepasang suami istri dengan dua orang anaknya, bernama Saedah yang laki-laki dan Saenih yang perempuan. Kedua suami istri itu bernama Ki Sarkawi dan Nyi Sarkawi. Pekerjaan Ki Sarkawi mencari kayu ke hutan. Oleh karena panggilan Allah Yang Maha Kuasa Nyi Sarkawi tidak dapat mengurus kedua anaknya itu sampai besar. Sebelum dia menghembuskan nafasnya yang terakhir, ia berpesan kepada suaminya bahwa kedua anaknya itu harus diurus baik-baik. Beberapa hari setelah istrinya meninggal dunia, Ki Sarkawi mencari istri lagi, dan akhirnya kawinlah.

Begitulah kisahnya, sehingga kedua anak itu mempunyai ibu tiri yang tidak senang kepada anak tirinya. Ibu tirinya bernama Maimunah. Demikian halnya dengan Saidah dan Saenih, dengan hati yang sabar tinggal bersama-sama dengan ayah ibu tirinya. Berhari-hari lamanya $\mathrm{Ki}$ Sarkawi pergi mencari pekerjaan ke hutan dengan meninggalkan keluarganya. Pada suatu hari ibu tiri pergi ke pasar, dia hanya berpesan kepada kedua anak tirinya untuk menjaga rumah, sedang soal makan anaknya, ibu tiri itu tidak bertanggung jawab sedikit pun.

"Saedah, awas janganlah sekali-kali kamu berani mengambil uang dan beras ini, dan jangan pula kau berani memakainya", demikian pesan ibu tiri itu kepada anaknya.

"Baik Bu". Jawab Saedah.

Dengan tidak mengingat waktu, ibu tiri itu bepergian, sedangkan kedua anaknya dibiarkannya menunggu di rumah. Oleh karena kedua anaknya tidak kuat lagi menahan lapar, akhirnya anak itu memberanikan diri untuk melanggar pesan ibu tirinya. Saedah yang pada mulanya takut kepada ibu tirinya, tetapi karena dia tak sampai hati melihat adiknya kelaparan, maka dimasaklah beras itu. Ibu tirinya marah-marah melihat beras dan uangnya dipakai oleh anak itu, begitulah nasib anak yang ditinggal bersama-sama ibu tiri. Dua minggu setelah anak itu dimarahi, datanglah ayahnya dari hutan. Dengan wajahnya yang sedih, kedua anak itu merangkul ayahnya, demikian pula ayah terhadap anaknya.

Melihat kedua anaknya yang sangat kurus, dimarahilah sang istri yang sangat kejam itu, dan dia bermaksud akan menceraikannya. Oleh karena takut dicerai, kemudian pergi ke dukun, dengan maksud supaya suaminya sayang kepadanya, dan dengan sendirinya akan membenci kedua anaknya itu.

"Pak, kalau engkau sayang pada saya, buanglah kedua anakmu itu", demikian kata istrinya itu.

"Baik $\mathrm{Bu}$, akan saya turuti segala kehendakmu", jawab laki-laki yang sudah kena guna-guna itu.

Malam harinya ketika kedua anak itu sedang nyenyak tidur, dibangunkanlah oleh ayahnya. Saedah dan Saenih terkejut, kemudian katanya:

"Mau kemana Ayah, pagi-pagi kami dibangunkan?" kata Saidah.

"Mau ke pasar Nak, mari kita bersenang-senang, biarkanlah ibu tirimu", jawab ayahnya.

Kedua anak itu tidak mempunyai perkiraan sedikit pun bahwa mereka akan dibuang sang ayah ke hutan. Dari rumahnya membawa nasi supaya anaknya mau diajak bepergian. Sampailah akhirnya ke tempat yang dituju. Baru saja sampai di hutan, Saenih minta minum. Alangkah bahagia ayah itu mendengar kehendak anaknya, karena dia berpikir bahwa pada waktu itulah kesempatan yang paling baik untuk meninggalkan kedua anaknya. Berjam-jam lamanya ayah itu pergi untuk mengambil air, tetapi bagaimana akhirnya, jangankan air, orangnya pun tidak muncul lagi. Begitulah perilaku seorang ayah yang sedang dimabuk cinta kepada istri muda, sehingga lupa akan tugas yang sebenarnya terhadap keluarga. Oleh karena lelahnya kedua anak itu menunggu ayahnya akhirnya Saedah pergi untuk menyusul ayahnya, sedang Saenih menunggu di tengah hutan. Waktu Saenih menangis di 
tengah hutan, datanglah seorang kakekkakek. Kemudian sang kakek menanyakan sebab-sebabnya dia tinggal seorang diri di tengah hutan. Saenih menceritakan segala sesuatunya kepada kakek itu. Diceritakan bahwa dia sengsara. Karena ibu tirinya maka dia dibuang. Mendengar pembicaraan Saenih, kakek itu bersedia membantu anak perempuan itu asal mau hidup sederhana. Saenih senang mendengar ucapan kakek yang mau mengurusnya.

Pada suatu hari di suatu kampungdiadakan suatu pertunjukan tarling. Kakek menyuruh Saenih pergi menonton tarling tersebut, dan kebetulan dalam pertunjukan itu kekurangan ronggeng. Saenih dipaksanya untuk menyanyi, akhirnya ia pun mau. Oleh karena dia baru belajar, banyak orang yang mengejek kejelekannya; akhirnya dia minta petunjuk kepada kakek, bagaimana supaya disenangi oleh semua orang. Kakek berpesan, jika ia ingin pandai dan ingin berbahagia, janganlah menyanyi lebih dari jam dua belas malam, dan jangan pula menerima uang pemberian lebih dari seratus rupiah. Oleh karena mujarabnya kakek itu, terkenallah nama Saenih di mana-mana. Lama kelamaan ia bertemu dengan kakaknya Saidah. Karena populernya nama Saenih, akhirnya Saenih menjadi kaya, tetapi sebagaimana kita ketahui bahwa segala kesenangan atau kekayaan di dunia ini tidak ada yang kekal. Begitu pula ia sudah sampai pada janjinya dengan kakek, maka ia akan dijemputnya.

Ketika Saenih sedang enakenaknya menyanyi, seolah-olah ada kereta api lewat. Saenih membicarakan hal itu kepada kakaknya.

"Kak, mengapa di depan kita ini ada benda hitam menuju ke sini?" kata Saenih.

"Itu adalah kereta yang kelak menjemputmu, sedangkan yang mengepul di atas adalah kemenyan supaya badanmu jadi harum", demikian jawab Saidah.

"Oh, Kak", Saenih mengeluarkan air matanya, "kalau begitu saya akan mati, tapi.......tidak apalah, memang sudah takdir saya. Hanya pesanku bawalah gelang dan kalung serta koper seisinya untuk pengganti beras dan uang yang saya pakai dahulu", jawabnya.

Ibu tiri beserta ayahnya mendengar bahwa anaknya sudah kaya dan bertempat tinggal di Desa Kali Sewo. Oleh karena kedua suami istri itu sudah tidak kaya lagi, maka mereka datang mengunjungi rumah anaknya. Kedua suami istri itu merangkul anaknya dan dia pun menyesali perbuatannya yang jahat itu. Ki Sarkawi bertanya kepada anaknya, "Nak, ke mana Saenih sekarang? Saedah menjawab bahwa Saenih sudah meninggal dunia, dan dikatakannya bahwa Saenih menyuruh untuk memberikan koper seisinya kepada ayah dan ibu sebagai pengganti beras dahulu. Ayahnya menangis menerima barang itu, kemudian suami istri itu pulang kembali ke rumahnya dengan melalui kali Sewo. Waktu kedua orang itu menyeberangi sungai tiba-tiba mereka jatuh ke sungai dan tenggelam ke dalam sungai tersebut.Mungkin sudah takdir kedua suami istri itu meninggal di dalam sungai dan dikuburkan di pinggir Kali Sewo itu. Sampai sekarang kuburan itu masih ada.

\section{Versi lainnya}

Di daerah Karang Turi, Indramayu, ada sebuah keluarga yang di kepalai oleh Sarkawi, dan beranggotakan istri Sarkawi dan dua orang anaknya, Saeda dan Saeni. Suatu saat Sarkawi pergi untuk naik haji. Tiba-tiba di tengah perjalanan Sarkawi tergoda dengan penari ronggeng yang bernama Maimunah.Sarkawi dan Maimunah akhirnya menikah tanpa sepengetahuan keluarganya di rumah ${ }^{2}$.

Sudah tujuh bulan lamanya Sarkawi tidak datang, istri Sarkawi sakit dan akhirnya meninggal dunia. Beberapa hari kemudian Sarkawi memutuskan untuk pulang ke kampung halaman serta membawa istri mudanya. Setiba di rumah

\footnotetext{
2 http://www.sundreamnews. com/ 2015/05/ jembatansewo-legenda-sang-rong-geng. Html diakses tanggal 20 Juli 201609.18
} 
Sarkawi terkejut karena mendengar kabar dari anaknya, bahwa ibu sudah meninggal. Setelah selang beberapa waktu, Sarkawi mengenalkan Maimunah sebagai ibu baru kepada Saeda dan Saeni.

Suatu saat, Sarkawi pergi bekerja, dan Maimunah pergi ke pasar. Maimunah berpesan kepada Saeda, Saeni "jangan pergunakan uang dan beras selagi ibu pergi". Namun karena Saeni lapar, lantas Saeda memasak beras untuk memberi adiknya makanan. Maimunah yang mengetahui hal itu langsung mencaci maki kedua anak tersebut.

Akan tetapi, karena merasa bersalah.Maimunah mengajak anak-anaknya berjalan jalan. Namun ada rasa kesal dalam diri Maimunah sehingga Saeda Saeni diterlantarkan di hutan

Hari sudah malam hanya ada Saeda, Saeni, dan binatang malam yang berada di tengah hutan. Ada seorang kakek tua mendekati Saeni, lalu ia memberi petunjuk kepada Saeni, bahwa Saeni akan dijadikan penari ronggeng tetapi mereka mengadakan perjanjian. Sesudahnya Saeni menjadi penari ronggeng dan Saeda jadi tukang kendang hidup mereka jauh lebih baik bahkan mereka berniatan untuk membayar hutang kepada ibu tirinya. Seiring waktu berlalu si kakek tua pun menagih janji, tak lama kemudian Saeni berubah menjadi buaya putih.

Melihat adiknya berubah wujud menjadi buaya putih Saeda langsung mengabarkan kepada orang tuanya di rumah, tanpa berpikir panjang Saeda dan orang tuanya menuju ke Sungai Sewo.Tak lama kemudian Sarkawi terjun ke sungai karena frustasi. Sarkawi pun berubah wujud menjadi bale kambang (balai yang mengambang). Begitu pula istri mudanya, Maimunah menjadi pring ori (bambu). Oleh karena melihat keluarganya sudah tidak ada semua, badan Saeda terasa lemas, Saeda menangis sejadi-jadinya dan berubah wujud menjadi sebuah pohon.

\section{Mitologi dalam Cerita Saedah Saenih}

Cerita rakyat Saedah Saenih dianggap oleh pendukungnya, masyarakat Indramayu seolah-olah cerita yang benarbenar ada. Cerita ini dipercaya pernah terjadi pada masyarakat Indramayu. Begitu kental dengan emosi masyarakat acapkali mendengar cerita ini, dari membaca buku, mendengar lantunan syair kisah ini, menonton film cerita ini atau menyaksikan dramanya akan diikuti dengan linangan air mata.

Apa yang dilukiskan dalam cerita ini merupakan cerminan masyarakat pendukungnya. Apa yang terjadi dalam cerita ini tidak asing dalam kehidupan mereka saat itu. Mereka tidak heran saat Saenih meminta ilmu kepada Si Kakek di hutan agar menjadi seorang ronggeng yang terkenal. Mereka tidak heran akhir kehidupan Saenih menjadi seekor buaya putih penghuni Sungai Sewo. Mereka tidak heran abangnya Saedah menjadi pohon di tepi sungai Sewo. Mereka tidak heran ketika ayahnya menceburkan diri ke sungai berubah menjadi bale kambang ( bale yang mengambang) dan ibu tirinya menjadi bambu (pring ori).

Masyarakat pendukungnya menganggap bahwa cerita itu benar-benar terjadi dan setiap kejadian yang terdapat dalam cerita memang benar-benar terjadi bukan sebuah dongeng atau khayalan.Anggapan ini bagi masyarakat sekarang dianggap sebagai mitos. Mitos artinya cerita yang seolah-olah benar-benar terjadi padahal sebenarnya tidak terjadi. Mitos berkaitan dengan kepercayaan masyarakat setempat atau kepercayaan masyarakat pada ruang dan kurun waktu tertentu.

Mitos sebagai produk budaya dapat dijadikan alat untuk memahami budaya sebuah kelompok masyarakat atau suku, termasuk pandangan kelompok tersebut terhadap posisi perempuan dalam keluarga. Dalam hal ini mitos berfungsi sebagai jendela budaya masyarakatnya. Dengan fungsi ini, penelitian terhadap mitos sangat mungkin dilakukan dengan sasaran memeroleh pemahaman mendalam 
mengenai berbagai aspek terkait bagi para seniman dan sastrawan di zaman masyarakat pemiliknya (Heksa, 2014:18). Reinasans. Di antara mitos-mitos di

Pengertian mitos dalam Kamus

Besar Bahasa Indonesia (KBBI) adalah cerita suatu bangsa; dewa dan pahlawan zaman dahulu, yang mengandung penafsiran; asal-usul semesta alam, manusia, dan bangsa itu sendiri yang mengandung arti mendalam yang diungkapkan dengan cara gaib (1995:660). Memitoskan artinya pengeramatan, pengagungan secara berlebih-lebihan; pahlawan, benda dan sebagainya; menjadikan mitos: mendewakan, kecenderungan seseorang perlu dicegah (1995:661). Pemitosan adalah proses, perbuatan, cara menjadikan mitos; pendewaan (1995:661).

Pengertian mitologi dalam Kamus

Besar Bahasa Indonesia (KBBI) adalah ilmu; bentuk sastra yang mengandung konsepsi dan dongeng suci mengenai kehidupan dewa dan makhluk halus di suatu kebudayaan (1995:660). Pengertian mitologi dalam Ensiklopedia Indonesia adalah kumpulan cerita tradisional, biasanya dari suatu bangsa atau rumpun bangsa tertentu, yang diceritakan secara lisan dari generasi ke generasi. Kebanyakan berasal dari masa sebelum aksara dikenal. Tiga golongan pertama mitos: mitos sebenarnya, yang merupakan daya usaha sungguh-sungguh dan imajinatif untuk menerangkan gejalagejala alam, dan sering menyangkut dewadewa serta peristiwa-peristiwa adi kodrati yang terjadi jauh di masa silam; cerita rakyat, termasuk dongeng adalah penurunan kisah-kisah dari masa sejarah yang menyangkut kehidupan masyarakat; dan saga serta legenda, yang menceritakan secara berbunga-bunga tentang tokoh masa lalu baik yang pernah ada maupun tidak. Istilah mitologi juga diterapkan terhadap ilmu pengetahuan yang mempelajari ceritacerita seperti di atas; daripadanya dapat dipikirkan tentang hubungan kebudayaan dan situs arkeologi sejarah. Mitologi telah sangat memperkaya kebudayaan dan terutama kesusastraan rakyat sedunia. Di Eropa mitologi klasik telah menjadi tema
Indonesia antara lain: Sangkuriang dan Lutung Kasarung yang melukiskan kompleks Oidipos dan Dora Sembad yang mengisahkan terjadinya aksara Jawa (1986: 2264).

Mitos atau mitologi kerap dirasa berada di luar batas pemikiran manusia. Pada awal masa kehidupannya, sebelum mengenal agama, manusia meyakini adanya dewa-dewa. Dewa digambarkan sebagai sesuatu yang hadir dengan mempunyai nama, bentuk, ciri-ciri, sifatsifat, dan kepribadian yang tegas. Selain itu, dewa pun memiliki kekuatan super, melebihi kemampuan manusia untuk menandingi maupun menalarnya. Gambaran ini terpatri dalam pikiran manusia berkat adanya dongeng-dongeng dan kesusasteraan suci (mitologi), baik yang lisan maupun tertulis (Koentjaraningrat, 2002: 2014).

Barthes mengatakan bahwa mitos adalah sebuah sistem komunikasi, sebuah pesan atau cara penandaan (signification) sebuah bentuk Mitos tidak ditentukan oleh objek pesannya, tetapi oleh cara dia mengutarakan pesan itu sendiri (2011: 152). Mitos mulanya dipahami sebagai imajinasi sederhana dan primitif untuk menyusun serangkaian cerita (Ratna, 2006: 67). Mitos dalam konteks strukturalisme Levi-Strauss tidak lain adalah dongeng (Ahimsa-Putra, 2006: 77). Junus mengatakan bahwa sebuah karya sastra, baik klasik maupun modern pada prinsipnya adalah mitos. Salah satu hal yang dapat dilakukan oleh karya sastra adalah membawa alam pikiran penikmatnya ke jalan yang dikehendaki oleh si pencipta karya. Dalam masyarakatnya, mitos ini mungkin bertugas untuk mengukuhkan sesuatu (mitos pengukuhan 'myth of concern'), mungkin juga bertugas untuk merombak sesuatu (mitos pembebasan 'myth of freedom') (1981: 84).

Dalam kehidupan masyarakat tempo dulu, kepercayaan yang berkaitan dengan dunia mitos dan takhayul sangat 
kuat, namun seiring perkembangan zaman kepercayaan semacam itu mulai memudar terutama di perkotaan. Kepercayaan semacam itu relatif masih ada di pedesaanpedesaan terutama yang jauh dari keramaian kota.

Mitos dan takhayul sulit dibedakan. Takhayul merupakan salah satu bentuk tradisi lisan yang sulit dipisahkan dari kehidupan masyarakat, baik masyarakat tradisional maupun masyarakat modern (Uniwati, 2012: 1). Takhayul sering juga disebut kepercayaan rakyat (folk belief) (Danandjaya, 1986: 153). Brunvand mengatakan bahwa takhayul mencakup aspek kepercayaan (belief), kelakuan (behaviour) pengalamanpengalaman (experiences), dan adakalanya berupa alat, ungkapan, serta sajak (1968: 1978).

Takhayul dalam KBBI diartikan dengan kepercayaan sesuatu yang dianggap ada atau sakti, tetapi sebenarnya tidak ada atau tidak sakti. Takhayul adalah halhal yang sering kita dengar dari orang tua kita atau kakek/nenek kita (2008:1380). Takhayul tersebut tentunya berawal dari banyak kasus yang terjadi karena melanggar pantangan dalam sebuah takhayul tersebut meski segala sesuatunya adalah bersandarkan atas kehendak Tuhan. Takhayul tersebut kemudian berkembang menjadi sebuah kepercayaan yang tidak berdasarkan pada logika sehingga dianggap tidak dapat dipertanggungjawabkan secara ilmiah (Danandjaya, 1986:153). Menurut Danandjaya bahwa takhayul menyangkut kepercayaan dan praktik (kebiasaan). Pada umumnya, takhayul diwariskan melalui media tutur kata (1986:154).

Masyarakat yang hidup di era sekarang, meskipun menganggap dirinya berada dalam kelompok masyarakat modern, namun tetap tidak dapat menghilangkan pengaruh-pengaruh orang tua dahulu. Pengaruh-pengaruh tersebut dapat berupa pandangan hidup dan pola pikir yang tidak dapat dilepaskan begitu saja (Uniwati, 2012: 2).
Dulu jalan pintas agar seseorang cepat menjadi kaya di antaranya dengan ngepet dalam bahasa Sunda nyegik atau munjung. Pelaku pergi ke suatu tempat keramat seperti Gunung Kawi untuk berguru dan mempelajari tekniknya. Pulang dari tempat keramat kemudian mempraktikan ilmu hitam (setan). Pelaku harus memakai pakaian seperti jubah kemudian berubah menjadi sesuatu misalnya babi, kera, dan binatang lainnya. Binatang ini yang nantinya bertugas mengambil uang dari dompet orang-orang kaya. Di rumahnya dipasangi lilin menyala, bila lilin mau mati berarti, pelaku sedang dalam keadaan bahaya. Lilin harus dijaga jangan sampai mati. Bila lilin mati berarti pelaku tertangkap. Cara ini dilakukan pada malam hari.

Dulu kalau seorang lajang atau bujang ingin mendapatkan cinta dengan cepat dan instan dari orang yang dikasihinya, maka dilakukan cara yang disebut pelet. Pelet yang terkenal di antaranya pelet Pagaden (daerah sekitar Sumedang Jawa Barat), pelet Sukabumi, pelet Banten, pelet Jampang, dan sebagainya. Pelaku harus memenuhi beberapa syarat yang diajukan oleh Sang Guru (dukun), jika sudah terpenuhi semua syarat baik berupa materi yang harus disediakan juga syarat yang harus dipenuhi langsung oleh si pelaku, misalnya harus puasa mutih, baca dzikir atau baca mantera, maka si pelaku sudah dianggap bisa menjalankan apa yang diinginkannya.

Dulu ketika orang ingin menjadi tenar, terkenal, dan disayang orang lain, dilakukan dengan cara memasang susuk. Susuk ini terbuat dari emas disimpan di jidat, muka, bahu atau di lengan. Bisanya agar khasiatnya terbukti, pelaku harus menjaga pantangan-pantangan dari Sang Guru (dukun).

Dulu orang jika ingin memiliki kekuatan harus berguru beberapa bulan bahkan tahunan. Dengan menjalankan syarat-syarat tertentu seperti harus puasa mutih, berdzikir, dan melaksanakan pantangan-pantangan tertentu, maka 
diyakini akan mendapatkan ilmu-ilmu tertentu seperti batra karang; ilmu kekebalan tubuh dari senjata tajam dan saepi angin; ilmu seperti layaknya angin. Jenis-jenis ilmu yang didapatkan digolongkan sebagai ilmu hitam; artinya ilmu yang terlarang karena melanggar ajaran dan aqidah Islam.

Dalam cerita rakyat Saedah Saenih, tokoh Saenih akhirnya memutuskan ingin menjadi seorang ronggeng yang terkenal agar menjadi orang kaya. Baginya sudah merasakan pahit getir menjadi orang miskin, namun cara yang ditempuh melanggar norma masyarakat dan ajaran agama. Saenih belajar dari seorang kakek, tokoh kakek inipun cukup misterius karena kemunculannya tiba-tiba di hutan. Apakah kakek ini makhluk halus atau orang yang berilmu. Perjanjian antara Saenih dan Kakek akhirnya membawa ketenaran Saenih. Saenih menjadi seorang ronggeng terkenal yang didambakan, digandrungi, dan menjadi idola saat itu. Ketenarannya menjadi ronggeng menghantarkannya menjadi seorang seniman yang kaya raya. Namun akhirnya di puncak kejayaannya, Saenih dijemput Sang Kakek dengan sebuah kereta kencana menuju ke dunia lain alias mati. Ini buah perjanjiannya dengan Sang Kakek. Setelah mati, Saenih dipercaya menjelma menjadi buaya putih penghuni Sungai Sewo.

Keberadaan jelmaan Saenih sampai sekarang dipercaya oleh masyarakat Indramayu khususnya masyarakat di sekitar Sungai Sewo. Jika ada kendaraan lewat Sungai Sewo tidak melempar uang maka akan mendapatkan petaka. Menurut penuturan masyarakat sekitar, di sekitar jembatan Sungai Sewo sering terjadi kecelakaan. Dulu pernah rombongan sebuah bis Dwi Warna dari Boyolali yang mengangkut transmigran ke Sumatera mengalami kecelakaan dan semua penumpangnya yakni 67 orang meninggal, peristiwanya terjadi tanggal 11 Maret 1974.

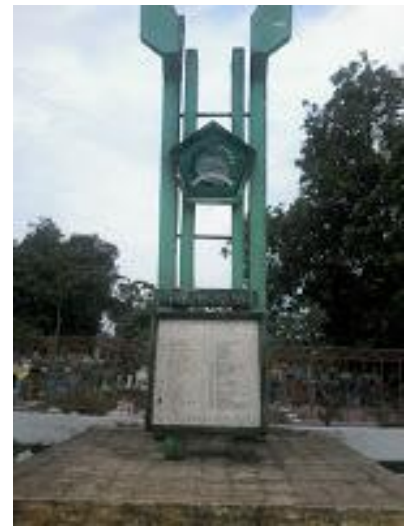

Gb. 2 Tugu Makam 67 Trasmigran yang mendapatkan kecelakaan di Jembatan Sewo. Sumber: http://www.sundreamnews. com/ 2015/05/jembatan-sewo-legenda-sang-ronggeng.html diakses tanggal 20 Juli2016

Di jembatan Sungai Sewo banyak orang, yang mengais keuntungan dengan mitos Saenih ini. Mereka meraup uang yang dilempar dari para pengendara. Cara mengambilnya dengan menyapu uang dari jalan ke pinggir kemudian memungutnya. Puluhan orang yang memanfaatkan momen tersebut, namun masyarakat tahu bahwa salah satu dari pemungut uang tersebut adalah makhluk halus.

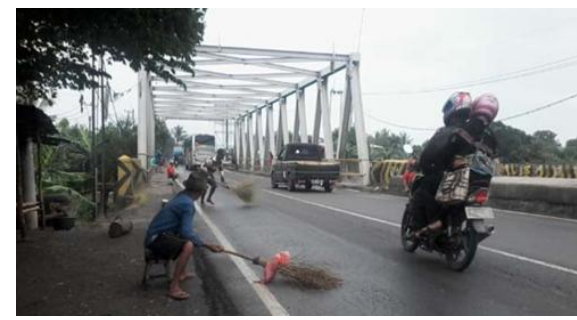

Gb. 1 Jembatan Sewo dan pengais rejeki Sumber: http://www.sundreamnews. com/ 2015/05/jembatan-sewo-legenda-sang-ronggeng.html diakses tanggal 20juli2016 09.18.

Masyarakat percaya bahwa Sarkawi dan Maemunah, istri mudanya yang sedih mendalam karena anaknya, Saenih mati menjadi buaya putih, menceburkan diri ke Sungai Sewo. Sarkawi berubah menjadi bale kambang (bale yang mengambang) sedangkan Maemunah berubah menjadi pring ori (bambu). Saedah yang sedih kehilangan keluarganya menangis sejadi-jadinya dan 
berubah menjadi pohon di tepi Sungai Sewo.

\section{Nilai Budaya dalam Cerita Saedah Saenih}

Banyak cara yang ditempuh leluhur (nenek moyang) untuk menasihati atau membimbing anak cucunya agar menjadi orang yang baik seperti dengan adanya pantangan (pamali), tali paranti (adat kebiasaan), pepatah (ujaran adat), dan legenda-legenda atau cerita rakyat. Yang terakhir ini adalah cerita rakyat, legenda termasuk folklor, dalam cerita ada pesan kesan yang ingin disampaikan. Pesan-pesan ini adalah sesuatu yang baik, yang bermakna dan membimbing anak cucunya agar selalu menjadi insan yang bermanfaat bagi sesama, lingkungan, dan Tuhannya.

Pesan atau isi dari sebuah cerita lazimnya disebut nilai-nilai luhur yang bermakna untuk kehidupan. Rene Wellek dan Austin Warren mengatakan bahwa dalam cerita mengandung unsur dulce et utile artinya menyenangkan dan berguna. Jadi sebuah cerita atau karya sastra tidak hanya mengandung unsur-unsur keindahan (estetis) namun ada pula unsur lain yang lebih penting yaitu tujuan tertentu yang dapat menjadi pengajaran atau acuan hidup bagi pembacanya. Koentjaraningrat mengatakan bahwa yang dimaksud dengan nilai budaya adalah tingkat yang paling abstrak dari adat yang terdiri atas konsepsikonsepsi, yang hidup dalam alam pikiran sebagian besar warga masyarakat, mengenai hal-hal yang harus mereka anggap bernilai bagi kehidupan manusia (1984:25).

Berdasarkan konsep nilai budaya yang dikemukakan Gazalba dan Sutan Takdir Alisyahbana, yang termasuk ke dalam konsepsi nilai budaya meliputi nilai agama, nilai filsafat, nilai seni, nilai kerja, nilai ilmu, nilai politik, nilai ekonomi, nilai sosial, nilai teori, nilai kuasa dan nilai solidaritas. Nilai budaya yang terdapat dalam cerita rakyat Saedah Saenih adalah nilai agama.
Dalam Kamus Besar Bahasa Indonesia (KBBI) agama adalah sistem, prinsip kepercayaan terhadap Tuhan atau Dewa dan sebagainya, dengan ajaran kewajiban-kewajiban dan kebaktian yang bertalian dengan kewajiban itu (1995:10).

Nilai agama atau nilai-nilai yang mengandung unsur keagamaan yang terdapat pada cerita Saedah Saenih adalah kurangnya fondasi agama sejak dini dari orang tua kepada anak. Hal tersebut menyebabkan dampak vital bagi sang anak di kemudian hari. Anak akan kehilangan pegangan hidup ketika berbenturan dengan masalah besar yang dihadapinya.

Dalam ajaran agama diterangkan bahwa orang tualah yang akan menjadikan anaknya, apakah menjadi seorang Muslim atau Yahudi, Nashrani, dan Majusi. Orang tualah, khususnya ibu yang akan menghantarkan anaknya menjadi baik atau tidak baik. Oleh karena seorang ibu memiliki ikatan batin dengan sang anak yang telah disusuinya dan ibu lebih banyak waktu di rumah untuk membimbing dan mengawasi anaknya. Dari Abu Hurairah RA. berkata, Rasulullah SAW. telah bersabda:

"Tidaklah setiap anak yang lahir
kecuali dilahirkan dalam
keadaan fitrah. Maka kedua
orang tuanyalah yang akan
menjadikannya sebagai Yahudi,
Nasrani, atau Majusi (Riwayat
Bukhari dalam Kitabul Jana`iz
No. 1358, 1359, 1385).

Orang tua sudah melalaikan tugasnya sebagai orang yang harus membekali anak ilmu agama. Hal ini dilakukan karena perjuangan akan godaan hidup di masa depan akan lebih berat dibandingkan generasi sebelumnya. Bekal ilmu keagamaan merupakan suatu keharusan dan kewajiban kepada putraputrinya. Dalam ajaran agama diterangkan bahwa bekali anak-anakmu karena mereka akan hidup dengan zaman yang berbeda dengan kita. Seorang sahabat Nabi Muhammad SAW yang bernama Umar bin Khatab RA., berkata: 
"Didiklah anak-anakmu, karena mereka akan hidup pada zaman yang berbeda dengan zamanmu”.

Akibat dari kurangnya pengetahuan agama sejak kecil, akhirnya sang anak akan mudah terjerumus ke dalam suatu kehidupan yang tidak dibenarkan oleh agama dan norma masyarakat. Saenih harus bergelut menjadi seorang seniman tenar yang digemari penonton dan menghasilkan uang yang melimpah. Namun cara yang ditempuh bertentangan dengan kelaziman pada umumnya. Cara yang ditempuh Saenih melanggar aturan agama dan norma masyarakat, yaitu mencari keuntungan dengan bantuan setan atau makhluk halus.

Kemiskinan adalah faktor utama

yang membebani keluarga Sarkawi, sehingga sering terjadi penganiayaan oleh ibu tirinya kepada anaknya, Saedah Saenih. Banyak tindakan berupa penganiayaan orang tua kepada anak karena alasan ekonomi atau kemiskinan. Dalam ajaran agama dijelaskan bahwa kemiskinan itu akan menyebabkan kepada kekufuran (kekafiran).

Dari Anas bin Mâlik RA. bahwa Rasûlullâh SAW bersabda, "Hampir saja kefakiran (kemiskinan) itu menjadi kekafiran" (Riwayat Baihaqi dalam kitab Syu'abul Imân No. 6612). Derajat hadits ini dhoif atau lemah.

Kemiskinan akan menyeret manusia untuk berbuat tidak baik dan tidak benar. Para pelanggar hukum yang harus menjalani hidupnya di Lembaga Pemasyarakatan (LP) kebanyakan adalah orang miskin. Mereka melakukan pencurian, penodongan, pencopetan, penjambretan, pembegalan bahkan sampai pembunuhan karena tuntutan ekonomi.

Begitu halnya yang dilakukan oleh Saenih, selain faktor fondasi agama yang lemah juga disebabkan faktor ekonomi. Saenih ingin kaya, Saenih ingin membayar semua makanan yang pernah dimakannya di rumah. Saenih ingin membahagiakan orang tua dan kakaknya, Saedah. Namun karena lemahnya pemahaman agama yang menyebabkan harus melanggar norma masyarakat dan melanggar aturan agama. Dalam pengajaran agama dijelaskan bahwa janganlah kamu meninggalkan anakanakmu menjadi anak yang lemah. Hendaklah membekali anakmu menjadi anak yang kuat baik ilmu agamanya, tingkat ekonominya, fisik yang kuat, dan ilmu pengetahuannya. Oleh karena dengan bekal kekuatan yang dimiliki akan menjadi filter atau benteng dari godaan-godaan yang akan menjerumuskannya.

Dan hendaklah takut kepada
Allah orang-orang yang
seandainya meninggalkan di
belakang mereka anak-anakyang
lemah, yang mereka khawatir
terhadap $\quad$ (kesejahteraan)
mereka. Oleh sebab itu hendak-
lah mereka bertakwa kepada
Allah dan hendaklah mereka
mengucapkan perkataan yang
benar (alQuran Surat an-Nisa
ayat 9).

Anak adalah titipan Tuhan, tugas orang tualah untuk memberikan perlindungan, pendidikan, kenyamanan, dan memenuhi kebutuhannya sesuai kemampuan orang tua. Dalam keterangan dijelaskan bahwa kelak di akhirat jika anaknya kelaparan atau tidak terpenuhi kebutuhan hidupnya maka bapaknyalah yang harus bertanggung jawab, namun jika anaknya memiliki perilaku atau akhlak tidak baik maka ibunyalah yang harus bertanggung jawab.

Keharmonisan orang tua dan rasa tanggung jawab orang tua terhadap masa depan anaknya, merupakan modal utama agar anak merasakan kasih sayang yang diinginkannya. Faktor orang tua dan pendidikan agama menghantarkan seorang anak menjadi penerus bangsa dan generasi bangsa yang akan membawa negara ke arah yang lebih maju, aman, dan sejahtera. 


\section{PENUTUP}

Tradisi lisan merupakan awal pertama kali manusia dalam berkarya untuk menuangkan apa yang ada dalam alam pikirannya. Tradisi lisan mencakup seluruh aspek budaya termasuk cerita rakyat, legenda atau folklor. Dalam cerita rakyat atau legenda dapat gambarkan kondisi masyarakat pemiliknya dalam ruang dan kurun waktu tertentu. Cerita rakyat pun dapat memberikan gambaran mengenai fungsi dan keberadaan cerita tersebut dalam kehidupan masyarakat pendukungnya.

Cerita rakyat, legenda atau folklor erat kaitannya dengan sistem religi. Sistem kepercayaan masyarakat pada ruang dan kurun waktu tertentu dapat digambarkan dari produk budayanya di antaranya dalam cerita rakyat atau legenda.

Kehidupan masyarakat yang digambarkan dalam cerita Saedah Saenih melukiskan keadaan masyarakat saat itu di Indramayu yang belum sejahtera. Kemiskinan melanda sebagian besar masyarakat, perekonomian mereka masih di bawah rata-rata atau berada dalam lapisan menengah ke bawah. Dengan tingkat perekonomian di bawah standar akan mudah terjadinya kekerasan atau penyimpangan kepercayaan.

Saedah Saenih diperlakukan tidak baik oleh kedua orang tuanya, ayah dan ibu tirinya. Perlakuan orang tuanya disebabkan karena beban ekonomi yang melanda keluarga tersebut. Akhirnya mereka dibuang ke hutan, Saenih memilih jalan kelam dengan menempuh ilmu hitam. Di bawah bimbingan kakek angkatnya di hutan, Saenih dibekali ilmu agar menjadi seorang ronggeng yang terkenal. Citacitanya tercapai, namun akhirnya Saenih harus menebusnya dengan mahal.Mati menjadi penghuni Sungai Sewo, menjelma jadi buaya putih.

Cerita Saedah Saenih mengandung unsur mitos seperti berilmu hitam untuk mendapatkan kekayaan secara singkat, Saenih dianggap menjadi buaya putih penghuni Sungai Sewo, ayahnya menjadi bale mengambang di sungai, ibu tirinya menjadi pring ori (bambu), dan Saedah menjadi pohon yang tumbuh di tepi Sungai Sewo. Masyarakat percaya bahwa cerita ini benar-benar terjadi, dan mereka percaya jika di Jembatan Sewo tidak melempar uang akan mendapatkan petaka.

Nilai budaya yang dapat dipetik dalam cerita Saedah Saenih adalah nilai agama yaitu pemahaman agama yang dimiliki Sarkawi dan Maemunah yang tidak memadai sehingga menelantarkan anaknya bahkan sampai tega membuang anaknya ke hutan. Akibat tanggung jawab orang tua untuk membekali pemahaman agama yang baik kepada anaknya tidak dapat dipenuhi, berakhir Saenih terjerumus ke dalam kehidupan yang melanggar norma masyarakat dan ajaran agama. Saenih yang tidak mendapatkan pendidikan Islam terjerumus dalam dunia hitam.

Penelitian ini dapat terlaksana dengan bantuan dari berbagai pihak yang tidak dapat disebutkan satu per satu. Oleh karena itu pada kesempatan ini penulis mengucapkan terima kasih kepada semua pihak. Semoga kebaikannya dapat bermanfaat bagi orang lain dan menjadi pahala bagi mereka.

\section{DAFTAR SUMBER}

\section{Jurnal}

Biopsi P.H., Heksa. "Mitos Oheo dan Asas Hubungan dalam Konsep O Rapu; Menguak Posisi Perempuan dalam Keluarga Suku Tolaki” dalam Patanjala Vol. 6 No. 1. Maret 2014. Hlm. 1-16.

Mulyani, Yeni. "Tradisi lisan dan Identitas Bangsa, Studi Kasus Kampung Adat Sinarresmi, Sukabumi" dalam Patanjala Vol. 4 No. 3. September 2012. Hlm. 407-418.

Uniwati. "Takhayul seputar Kehamilan dan Kelahiran dalam pandangan Orang Labuan Bajo; Tinjauan Antropologi" dalam Patanjala Vol. 4 No. 1 Maret 2012. 


\section{Buku}

Ahimsa-Putra, Heddy Shri. 2006. Strukturalisme Levi-Strauss, Mitos, dan Karya sastra. Yogyakarta: Penerbit Kepel Press.

Ali, Lukman. 1995.

Kamus Besar Bahasa Indonesia, Edisi Kedua. Balai Pustaka: Jakarta.

Alisyahbana, Sutan Takdir. 1977. Perkembangan Sejarah Kebudayaan Indonesia Dilihat dari Segi NilaiNilai. Jakarta: Idaya.

Barthes, Roland. 2010.

Imaji, Musik, Teks: Analisis Semiologi atas Fotografi, Iklan, Film, Musik, Alkitab, Penulisan dan Pembacaan serta Kritik Sastra. Agustinus Hartono (penerjemah). Bantul: Kreasi Wacana.

Bogdan, Robert C. 1972.

Participant Oberservation in Organizational Settings, Syracuse, N.Y.: Syracuse University Press.

Brunvand, Jan Harold. 1968.

The Study of Americaan Folklore-An Introduction. New York: W.W. Norton \& Co.Inc.

Dananjaya, James. 1986.

Folklor Indonesia: Ilmu Gosip, Dongeng, dan lain-lain. Jakarta: Pustka Grafitipers. 2008.

"Pendekatan Folklore dalam Penelitian Bahan-Bahan Tradisi Lisan" dalam Pudentia (Editor). Metodologi Kajian Tradisi Lisan. Jakarta: Asosiasi Tradisi Lisan.

Dasuki, HA.1964.

Sejarah Indramayu (Cetakan ke-2). Indramayu: Sudiam.

Dienaputra, Reiza D. 2005.

"Sejarah Kertas di Indonesia" dalam Sabana dan Hawe Setiawan (Editor) Legenda Kertas. Bandung: Kiblat.

Ekadjati, Edi. 2005.

"Melestarikan Naskah Sunda" dalam Sabana dan Hawe Setiawan (Editor) Legenda Kertas. Bandung : Kiblat.
Gazalba, Sidi. 1973.

Sistematika Filsafat Pengantar Teori Nilai. Jakarta: Bulan Bintang.

Junus, Umar. 1981.

Mitos dan Komunikasi. Jakarta: Sinar Harapan.

Kahmad, DR.H. Dadang. 2000.

Metode Penelitian Agama, Perspektif Ilmu Perbandingan Agama. Bandung: Pustaka Setia.

Koentjaraningrat et.al.1984.

Kebudayaan Mentalitas dan Pembangunan. Jakarta: Gramedia. 2002.

Pengantar Antropologi II. Jakarta: Rineka Cipta.

Moleong, DR. Lexy J. 1989.

Metodologi Penelitian Kualitatif.

Bandung: Remaja Karya.

Ratna, Nyoman Kutha. 2006.

Teori, Metode, dan Teknik Penelitian Sastra: dari Strukturalisme hingga Postrukturalisme, Perspektif Wacana Naratif. Yogyakarta: Pustaka Pelajar. 2010

Metodologi Penelitian Kajian Budaya dan Ilmu Sosial Humaniora pada Umumnya. Yogyakarta: Pustaka Pelajar.

Renne Wellek \& Austin. 1989.

Teori Kesusastraan. Jakarta: Gramedia.

Shadily, Hassan. 1986.

Ensiklopedi Indonesia. Jakarta: Ikhtiar Baru-Van Hoeve.

Sugono, Dendy. 2008.

Kamus Besar Bahasa Indonesia (Cetakan Pertama Edisi IV). Jakarta: Gramedia.

Surakhmad, Winarno. 1982.

Penelitian Dasar Metode Teknis. Bandung: Tarsito. 


\section{Internet}

http://penaraka.blogspot.co.id/2012/04/pe-

ngertian-agama.html, diakses tanggal 23 Mei 2016 pukul 15.45 .

https://id.wikipedia.org/wiki/Kabupaten_Indra mayu diakses 19 juli2016 15.47.

http://www.sundreamnews. com/ 2015/05/ jembatan-sewo-legenda-sang-ronggeng.html diakses tanggal 20juli2016 09.18 . 